\title{
Introduction by Denise Brahimi ${ }^{1}$
}

Hubertine Auclert was a passionate feminist, driven as much by her emotions as by her political and intellectual convictions. Will France ever see the day when the word "suffragette" will no longer poke fun of those who, like her, fought for decades so that women would finally obtain the vote? Even though today's laws and mores have at last recognized many feminist claims, the word "suffragette" still evokes the comical image of a fat lady ferociously shaking the ostrich feather of her hat. It is hard to believe, but...

Paradoxically, Hubertine Auclert had everything it takes to embody the most solid virtues of la France profonde. ${ }^{2}$ Born in 1848 into the provincial bourgeoisie of central France, she received the religious education considered the most appropriate for young women in the Second Empire; she put up with it as well as she could, but apparently did not fight it. In the early 1870s she already showed the originality of character and the commitments that would be hers throughout her life. She entered adult life at twenty-three, which for her meant leaving the province for Paris and, having come into an inheritance at the death of her parents, being financially independent.

Her social situation in the France of the Third Republic certainly had consequences for the nature of her claims in Algeria as well as in France. Deeply involved in the French women's movement, she found it difficult, despite serious attempts, to associate herself as a feminist with the collectivist-socialist movements, though she was sometimes close to them, especially in the 1880-1890s. In Algeria, she could not bear the sight of misery and destitution and found unthinkable to adopt a life style " $\grave{a}$ l'arabe" as did Isabelle Eberhardt, who lived in Algeria from 1898 to 1904. One never finds any pity for the poor in Eberhardt's writings, for she herself was poor, partly out of necessity, partly out of choice. However, it would be absurd to blame Hubertine Auclert (less peculiar on this point than the astonishing Isabelle Eberhardt) for her desire to improve the life of the needy, which the very aristocratic and anti-republican Isabelle Eberhardt contemptuously rejected.

As soon as she was independent and time was her own, Hubertine Auclert devoted herself wholeheartedly to several feminist campaigns, aimed mostly at obtaining the right to vote for women, an option which, even within the women's movement, was not the majority tendency. She did it as a republican and an advocate of democracy, two traits that would also characterize her reactions to colonial Algeria.

1 This introduction was written by Denise Brahimi for the reedition of Les Femmes arabes en Algérie, published in 2009 in Paris by the Editions L'Harmattan in the collection Autrement Mêmes. I am grateful to the author, the series editor Roger Little, and the Editions L'Harmattan for their generous permission to translate it. JGB

2 These words refer to the deep cultural aspects of French provincial towns and villages, in opposition to the dominance of Paris. 
She was a republican, both by family tradition and by personal conviction. Her father, who was involved in political activities in 1848, opposed Napoleon III after the coup d'Etat of 1852 until his death in 1861. The Franco-Prussian war of 1870 triggered in her a great élan of republican patriotism and she felt grateful to the Arab battalions recruited in Algeria for their help at that time. As a citizen of the Third Republic, she was convinced that she lived in a country where all citizens had an equal right to play a part in the political arena and she saw no good reason why women should be deprived of that right. This is why she deemed it essential to work for women's suffrage, the only way for them to cease being "slaves," according to the term used by Victor Hugo whom she admired.

She was an activist. In 1876, she founded the society Le Droit des Femmes which became Le Suffrage des Femmes in 1883. In 1882, she founded the newspaper La Citoyenne which received the support of Séverine, a well known feminist.

In addition to her demand for women's political rights, she fought against the legal rules governing divorce and advocated a marriage contract with the separation of property so that divorced women could have control of their earnings. We shall see how, in Algeria also, she researched the legal conditions of marriage and attempted to improve them.

But before following her to that country where she went as the wife of Antonin Lévrier, it is interesting to know how this feminist managed -or didn't manage- the privileged relationship with a man; at least we know that he wooed her for years before she consented to marry him.

Although she remained very discreet on this subject, Hubertine Auclert certainly was emotionally lonely for a great part of her life; her extremist and very demanding views alienated her from many people, among them her feminist mentors, Léon Richer (author of La Femme libre published in 1877) and Maria Deraisme (author of a book entitled Eve dans l'humanité in 1868). A feeling of deep friendship bound her to Antonin Lévrier, whereas he was very much in love with her and proposed to her several times. In the early 1880 s her refusal was motivated, it seems, by her opposition to the French laws governing marriage and the submission they imposed on the female sex. When Antonin Lévrier, first a lawyer then a juge de paix, ${ }^{3}$ was obliged to be away from her, particularly when he was appointed to a post in Tahiti, she missed him badly and also felt guilty knowing that he was alone. In the beginning of the year 1888, he obtained a post in Algeria; he was already gravely ill with the tuberculosis that would cause his death; she was fully aware of the facts when she accepted marriage in order to be with him. They probably enjoyed very happy moments together in Algeria: they shared the same convictions and had the same concern for justice, he by profession, she by commitment. However, it took special circumstances for her to accept marriage, only once in her life.

3 Magistrate who rules alone on civil cases only. 
Hubertine Auclert did not decide herself to live in Algeria, since she only went there to accompany Antonin Lévrier, her husband. Nonetheless, one should not speak of it as fortuitous, for it is true that her four years (1888-1892) in that country turned out to be the opportunity to verify, with terrible evidence, the validity of her theses and of her struggles. Her observations in the field, in this jewel of the French colonies, benefited from the work she had been doing in France for the last two decades. When she arrived in Algeria, she was a forty-year-old woman, sure of herself, confident in her skills, and accustomed to fighting for her ideas without being discouraged by setbacks.

To lead the fight in this new terrain, she took advantage of a favorable circumstance, that of being a judge's wife. Most of her supporting documentation evidently came from the experience acquired by her husband in his role of juge de paix: that is to say, the numerous suits brought by women seeking to obtain a divorce or damages, or sometimes women judged for having committed crimes that were the consequence of polygamy. This is how Hubertine Auclert came to understand one of the main flaws of marriage Algerian style; as a militant feminist she denounced it all the more violently because she was convinced that she was giving voice to the opinion of the "Musulmanes." 4

Furthermore, more than an intellectual she was a field-worker engaged in an independent investigation; this was possible because nothing could be refused to a representative of the French State in an Algeria subjected to the colonial rule. In any case, the Arab women, she said, really wished to be heard, especially by another woman, and wanted nothing more than to talk to her.

\section{Two New Themes}

Living in Algeria brought Hubertine Auclert two new themes to add to those that never ceased to be hers. They were on the one hand a very strong reaction to the ambient racism, and on the other a blunt criticism of colonialism as it was practiced, even though she did not question the principle of colonization upheld by the government of the Third Republic which, on the whole, she supported. This is why she cannot be defined by the term "anti-colonialist" despite her vehement attacks against the official or private behaviors she witnessed. At the time of her residence in Algeria, anti-colonialism was still a subject raised by the political right or rights that attacked the republican government. The following decade saw a major change with the emergence of an anti-colonialism from the left, represented by Vigné d'Octon (1859-1943). One of his first books, reedited a quarter of a century ago, was entitled

4 Muslim women. 
La Gloire du sabre ${ }^{5}$ it was an extremely violent pamphlet against the colonial presence in the Maghreb. This confrontation between the two authors reinforces our conviction that Hubertine Auclert was in many ways a precursor.

If further proof were needed, it would be what she wrote about the possible role of Arab battalions used as auxiliary troops in the wars of the Republic. From what she had seen and experienced in 1870-1871, she imagined a possible recourse to these troops, which, as we know, became a reality in the First World War. Nor was it difficult for a woman like her to foresee France's ingratitude towards them, for which one should still be ashamed today.

Instead of using the word "racism," she spoke with violent indignation of the "prejudice of race," this permitted her to assimilate it to the "prejudice of gender," her favorite subject. Her denunciation of the racial prejudice was both general, of the order of inalienable principles, and particular in the case of Algeria. What struck her in that country was that, to use her words, Arabs were handsome, quick, intelligent - the children, who amazed her, as well as the adults, the men as well as the women. Racism toward them was a kind of denial of reality. So she directly placed herself in the tradition of Enlightenment thinking when she attributed it to prejudice, which is a matter of education, hence the necessity of establishing schools, and a matter of socio-political organization, hence her criticism of the colonial regime practiced in Algeria.

The racial prejudice was part of the colonial system and one of its foundations. It claimed to justify many behaviors that she, on the contrary, violently denounced as not worthy of the French Republic. For those whom she called the Algerians according to the usage of the time, that is, the Europeans, mainly the French implanted in the country, considering the Arabs as inferior beings was a pretext for refusing them all rights and treating them daily in a way unworthy of a human being.

So now more forcefully than ever, she put forth the demands on which she focused in France: the Arabs must have the right to vote, they must be able to defend themselves against the abuses of the authorities by choosing their own representatives.

The democratic component of this demand led her to denounce very precise facts. In Algeria, the French colonial rulers leaned on a very small indigenous "aristocracy" ready to deal with them in order to keep their privileges. Consequently, Arabs should be represented differently, by persons elected by the people, for whom this aristocracy had no concern.

However, it is obvious, as the title of her book indicates, that Hubertine Auclert was touched more by the deplorable condition of women than by any other injustice,

5 P. V. d'Octon, La Gloire du sabre, Paris: Société d'éditions littéraires, 1900 (same publisher, same date as Les Femmes arabes en Algérie); reedited with an introduction by Jean Suret-Canale, Paris: Quintette, 1984. See also La Sueur du burnous: les crimes coloniaux de la Ille République, Paris: Editions Guerre sociale, 1911; reedited with a postface by Maurice Rajsfus, Paris: Les Nuits rouges, 2001. 
and felt the pressing importance to improve it. There is no doubt: she first reacted emotionally to what she saw and what she heard, then soon moved to action in the various militant ways she knew from having practiced them in France. Arab women were miserable in Algeria, scorned and rejected everywhere; in Flora Tristan's word which was also Hubertine's they were pariahs; it was necessary and urgent to launch a fight on several fronts, while privileging two in particular: education, by demanding schools for girls, and marriage, by opposing polygamy.

\section{The Education of Arab Girls}

Hubertine Auclert's report on the first question shows the seriousness of her investigations. Indeed, as she recounted, schools for girls had been created in the years 1840 to 1860 . Then, probably upon the request of influential notables, it was decided to close them and replace them by some ouvroirs devoted to needlework, even if it meant sending back the courageous female teachers who had come to Algeria to accomplish a mission of education.

Among the testimonies we have on this subject, there is that of Fadhma Ait Mansour Amrouche. In her autobiography, Histoire de ma vie, ${ }^{6}$ she narrates how things happened in her village in Kabylia and how the school she loved so much was closed in the years 1890-1895. Obviously it takes great perversity to give girls the taste for education then deprive them of it, and Fadhma never forgot her cruel disappointment. This is why in the 1946 dedication of her book, she said she wrote it both in her mother's memory and in homage to her teacher, "Madame Malaval who gave me my spiritual life."

The school conceived by Mme Malaval in the early 1890s was the exact copy of the French school, the famous school of the Third Republic, secular, free, and compulsory, the virtues of which are still mourned today. But her success excited jealousy and contestation, and she was fired. Here is what Fadhma wrote in 1893, amply confirming the observations gathered by Hubertine Auclert a little earlier:

People were beginning to demand the emancipation of Muslim women. At that time school was compulsory for boys; if a pupil played truant, the father and son were sentenced to three days in prison and a fine of fifteen francs. So boys attended school regularly. But, alas! Nothing similar was enforced for girls. There was no secular teaching for them, with the exception of our school which unfortunately had to close.

In fact, M. Masselot came to see us and told us that the commune could not bear the costs of the orphanage any longer, so the school must close and the pupils be sent back to their families. He had us stand in rows and said, “I can't help you.

6 F. A.M. Amrouche, Histoire de ma vie, Paris: Maspero, 1968. In English Fadhma A. M. Amrouche, My Life Story, translated by Dorothy Blair, London: The Women's Press, 1988. 
If you were men I'd issue you with a burnouse and give you a job in the police or the horse regiment, but you are girls...” And he added casually, "They're pretty, they'll get married...!"

Mme Marval refused to obey; she kept the orphanage going for six months out of her own savings; she moved heaven and earth, writing to members of the government and any influential persons who might help her. ${ }^{7}$

Even though Fadhma did not say anything about it, one can imagine that Mme Malaval's action was inspired by Hubertine Auclert's example a short time earlier.

On the debates sparked by the question of schooling for girls, much information can be found in a study that unhappily limited its investigations to 1880. It is the work of Yvonne Turin, Affrontements culturels dans l'Algérie coloniale, écoles, médecines, religion, $1830-1880 .{ }^{8}$ To read it is to realize that Hubertine Auclert raised this question on a terrain that had been problematic and troubled for a long time, marked, among others, by Mme Luce's initiatives recounted in Les Femmes arabes en Algérie. Here, for example, are some reflections on the importance and difficulty of debates concerning this question that lasted for several decades:

The education of girls triggers in all, Europeans or Arabs, Christians or Muslims, a series of passionate reactions which, in a chain movement, achieve nothing less than to make and unmake societies! Some people imagine the possible marriages between students of boys schools and students of girls schools (Mme Luce doesn't fail to suggest them) and all the offspring of this biracial culture multiplying in geometric progression; others hide their face from the attacks inflicted on a tradition rooted in a socio-religious foundation, attacks that can only bring upon them the punishment of an apocalyptic anger. It is not possible to speak about Arab-French schools for girls without evoking this psychological and passionate foundation: a background that grows as one seeks not only to teach little girls but also to educate them and convert them into the foundations of a new world. ${ }^{9}$

It is remarkable that the word "passionate," so appropriate for Hubertine Auclert, is used by Yvonne Turin to describe these debates. At the end of the 1880s, our valiant feminist witnessed more of them, which was certainly not going to make her retreat, but she would surely have needed many more than four years to bring about any progress in this vast area.

7 F. A. M. Amrouche, pp. 17-18.

8 Y. Turin, Affrontements culturels dans l'Algérie coloniale, écoles, médecines, religion, 1830-1880, Paris: Maspero, 1971.

9 Y. Turin, pp. 268-269, transl. JGB. 


\section{Polygamy}

There is no doubt Hubertine Auclert found many examples of the ill effects of polygamy, if only the women's despair when their husbands brought home a new spouse. Here too she carried on the tradition of the Enlightenment, especially Montesquieu. One feels that her book contains several elements of a dossier that she might be building in order to ask "monogamous France" to forbid polygamy in its colony; by confronting these two terms she underlined the incoherence of French policy. It seems, however, that her research and her action were interrupted by her precipitous departure from Algeria, as she said herself. We must take this circumstance into account to understand the somewhat disconcerting form of her book.

It is a known fact that this unexpected departure in 1892 after four years is linked to her husband's death. Naturally, other tasks were awaiting her in France, and she soon turned to them at the expense of the work she had accomplished in Algeria. This is why her book, which she wanted devoted to Arab women, was published with an eight-year delay in 1900. Very possibly, this delay can also be explained by the publishers' reluctance to tackle an even more delicate subject than feminism alone, since the polemic included a vehement criticism of the colonial system. It seems, however, that Hubertine Auclert had little time to put much care into this book, even though she had numerous elements to write it. It lacks structure, to say the least, the various fragments being juxtaposed without any apparent thematic grouping. Most of the text was not reread, it might be a first draft; it shows the author's sincere eagerness, but also her lack of interest in the time-consuming care required in writing.

About the publication of Les Femmes arabes en Algérie, it should be noted that Hubertine presented her book under her maiden name, Auclert, which is not surprising since she never took her husband's, Antonin Lévrier, despite her great esteem for him. Obviously it was a matter of principle, and it is interesting to see that she did raise that question in the book in a comparison that, this time (and it is not the only one) gives the advantage to the Arab women, whereas the French tradition is severely criticized:

A Muslim woman keeps her name when she marries. Messaouda bent (daughter) Djaffar remains Messaouda bent Djaffar after her marriage to Aïssa ben (son) Lakdar. One would not know her if she changed her name as often as she changes her master. She wisely keeps her own, which is not the case for us, and instead of annihilating her personality like a French woman, she enlarges it; with marriage she acquires a sort of civil and economic emancipation. ${ }^{10}$

This makes it clear that the militant feminist never forgot her objectives, which as a whole applied even more to France than to Algeria. It is obvious, however, that

10 See p. 16. 
the women of that other country and of that other culture, as we say today, raised very specific problems for which Auclert had to acquire a considerable amount of information in the space of four years.

Because her book does not present the facts in an organized fashion, a certain impression of confusion can prevail. On the precise subject of the book, that is, the condition of Arab women in Algeria, it is true that Hubertine Auclert put forward a variety of opinions: sometimes she expressed an immense pity for their status of slaves, other times she voiced admiration, even a kind of envy, for advantages or qualities that French women did not have. Yet she did not invent this diversity which, indeed, was very real; but because she was neither a sociologist nor an ethnologist, she did not provide the analysis necessary to explain it.

\section{A Plurality of Life Styles}

After more than a century rich in numerous research studies, one can suggest today several paths that created an undisputable plurality. Oversimplifying, it appears that at the time of Hubertine Auclert's journey, around 1890, the life style of Arab women stemmed from three different sources, and whereas she had the opportunity to observe their manifestations or their effects, she could not always distinguish them clearly.

The first source is the Arab tradition, that is, specifically, the Bedouin tradition. Hubertine Auclert had the opportunity to observe it in the south where she lived with her husband in what at first looked to them like paradise. The women belonging to tribes of nomadic origin often impressed her by the freedom of their ways, their boldness, and their beauty. To evoke them, the feminist recalled the pagan, that is, pre-Islamic Arabia which, as most scholars agreed, contained important traces of matriarchy. Furthermore, the Prophet himself, in the Koran, and the Islamic tradition that followed it closely gave women guarantees and advantages (in the matter of inheritance, for example) that they did not have before. Admittedly, the Prophet was polygamous, but it seems that his spouses enjoyed a wide freedom.

Testimonies abound about the courage of Arab women who lived during these heroic times and about their participation in tribal battles. Evidently, their memory had been rekindled during the early period of the French conquest of Algeria, and Hubertine Auclert had heard about warlike exploits accomplished by courageous, indeed ferocious, women. In his book entitled Femmes d'Algérie: légendes, tradition, histoire, littérature, ${ }^{11}$ Jean Déjeux evokes some of them, whose names soon became legend.In France, Louis Massignon ${ }^{12}$ did not hesitate to compare one of these resistants, Lalla Fathma n'Soumeur, to Joan of Arc. Jean Déjeux also recalls Maupassant's

11 J. Déjeux, Femmes d'Algérie: légendes, tradition, histoire, littérature, Paris: La Boîte à Documents, 1987.

12 Louis Massignon (1883-1962), Catholic scholar of Islam and the Islamic world. 
testimony about the frightening involvement of women in the insurrection of Bou Amama in 1881, only a few years before Hubertine Auclert's arrival in Algeria. Reading her book, one feels that she must have heard stories about these combatants during her inquiries, whereas, more often than not, she could not fail to notice, particularly in the streets of Algiers, the presence of submissive, crushed women.

The second source is the Mediterranean tradition found in many of the countries, Christian as well as Muslim, situated along that sea. It was certainly much less favorable to women than the first one, forcing on them a much harder daily life, which has sometimes been dated back to the Neolithic age when agriculture required a large amount of human toil.

Such is the thesis developed by Germaine Tillion in her still famous and widely used book, Le Harem et les Cousins, ${ }^{13}$ the essence of which is very clear in the following lines written by the author:

If one examines on the map the distribution of women's enslavement, one notices that it corresponds to the shores of the Mediterranean, that is, to the most ancient civilized people of our planet, the first beneficiaries of the Neolithic revolution, an optimistic and ferocious revolution to which we owe the bread, the beefsteak, and the butter.

But also war and slavery. ${ }^{14}$

That was when patriarchy developed in the authoritative form that, until the $20^{\text {th }}$ century, could still be found in some rural societies where it gave a man the power of life and death over his wife and children.

The third source, finally, is the colonial system, from which one might have expected favorable effects for women, but which brought the opposite. It had been in existence for more than fifty years when Hubertine Auclert observed its effects in Algeria, where it led to a considerable debasement of the Arab life style, for men as well as for women. However, women were even more the victims of a perversity inherent in this regime because the French administration struck a horrible bargain at their expense: the colonial authorities would let Arab men treat their wives as they wished and according to the worst of their customs - provided that in exchange the colonial authorities could freely grab the land and despoil the nomadic, semi-nomadic, and sedentary tribes. It was easy for Hubertine Auclert to denounce the hypocrisy of the authorities who rejected, in the name of their respect for Muslim law, any law or decree that attempted to improve the life of women. It was obviously a terrible joke.

In any case, it should be noted that until the eve of independence, the French colonial authorities permitted customary, absolutely shameful and unimaginable

13 G. Tillion, Le Harem et les Cousins, Paris: Seuil, 1966. In English: G. Tillion, The Republic of Cousins: Women's Oppression in Mediterranean Society, translated by Quentin Hoare, London: Al Saki Books, 1983.

14 G. Tillion, The Republic of Cousins, back cover. 
behaviors to persist in the middle of Algiers. They knew about them but considered them once more to be the concern of the famous Muslim laws that were none of French business! One of the most unbearable testimonies on this matter is the book written by Zoubeïda Bittari under the very explicit title $O$ mes soeurs musulmanes, pleurez! ${ }^{15}$ If I am tempted to mention it here, it is because, on this terribly painful subject, it recalls Hubertine Auclert's tone and style, even though to us it seems excessive at times (but it is true that this arguable opinion may be the way to protect ourselves, even mentally, against recalling unacceptable violence). The book's author, born in 1939 into a well-to-do family of Algiers' bourgeoisie, was nonetheless married at twelve and a half against her will, was a mother the following year, then repudiated by her husband, and rejected by her own family. One can see that, for some women at least, the situation was still unchanged sixty years after Hubertine Auclert's reports.

An argument often invoked against this type of testimony is that the facts she described had nothing to do with Muslim law, but with the total corruption of a certain tradition. It is indeed possible that Hubertine Auclert sometimes confused this law with popular traditional customs. But that is not the important thing, and her reports stay what they are. A militant like her would hardly listen to such quibbling!

Hubertine Auclert was neither a scholar nor an impeccable analyst. But the power of what she wrote will touch the reader deeply; it comes from her ability to communicate her indignation, her pain, and her pity in images. We feel it in the very first lines of her book, when it turns out that "the shocking bundles of dirty linen" that move on Algiers' cobblestones are Arab women. There are many other examples in the text which is compelling for its emotional strength if not for the rigor of its argumentation.

Denise Brahimi

15 Z. Bittari, O mes soeurs musulmanes, pleurez!, Paris: Gallimard, 1964. 